\title{
Effect of incorporated or mulched compost on leaf nutrient concentrations and performance of Vitis vinifera $\mathrm{cv}$. Merlot
}

\author{
T.-T. Nguyen ${ }^{1 *}$, S. Fuentes ${ }^{1}$, P. Marschner ${ }^{1}$

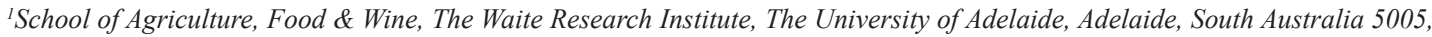 \\ Australia."Corresponding author: trung.nguyen@adelaide.edu.au.
}

\begin{abstract}
Compost can reduce evaporation and increase nutrient uptake by plants, but it is not clear if it can increase soil water holding capacity or stimulate leaf gas exchange, water use efficiency and yield of vines. To study these effects, compost from garden and food waste was incorporated or mulched in a vineyard at a rate of $100 \mathrm{~m}^{3} \mathrm{ha}^{-1}$, three months before the measurements. The vineyard received irrigation during spring and summer. Soil water content was monitored regularly with a capacitance probe. Photosynthesis, transpiration, stem water potential and leaf area index were measured several times during the vegetation period. At harvest, yield, berry weight and quality as well as chlorophyll, N, P and K concentrations in leaves were determined. Only mulched compost increased soil water content at $10 \mathrm{~cm}$ depth, but the water content in the deeper layers was not affected by compost addition. Compost also did not affect transpiration rate and stomatal conductance during the vegetation period, but mulched compost increased the photosynthesis per plant at flowering, pea size and maturity periods. Compost amendment, particularly mulching, increased yield, specific berry weight, and leaf $\mathrm{N}$ and $\mathrm{P}$ concentrations, and reduced the number of chlorotic leaves at harvest. Berry quality was not affected by compost amendment. It can be concluded that mulched compost has a positive effect on grapevine yield and can be an alternative fertiliser source for vines with no adverse effect on berry quality.
\end{abstract}

Keywords: Gas exchange, grapevine, organic amendment, mulched compost, soil water content

\section{Introduction}

Plant water availability is an important limiting factor for current and future viticulture, particularly because a large proportion of the area used for viticulture is located in semi-arid climates. In addition, the growth period of grapevines often coincides with the dry period during which there is a higher atmospheric demand for water. Therefore, many growers have to rely more and more on irrigation to obtain adequate yields. Climate change modelling indicates an increase in aridity in the current growing area which could help a negative effect on yield and quality of grapes (Chaves et al., 2007).

Compost is widely used in agriculture and horticulture, and it has been recently trialled for grapevine (Pinamonti, 1998; Korboulewsky et al., 2004; Powell et al., 2007). 
The general benefits of compost addition are increasing soil water holding capacity (Aggelides and Londra, 2000; Curtis and Claassen, 2005; Mylavarapu and Zinati, 2009), providing nutrients and organic matter, as well as improving soil physical properties, including soil structural stability (Tejada et al., 2009), total porosity (Jamroz and Drozd, 1999; Aggelides and Londra, 2000), aggregate formation (Celik et al., 2004; Sodhi et al., 2009) and hydraulic conductivity (Curtis and Claassen, 2009). Therefore, compost application could be useful in vineyard management to increase water use efficiency and reduce irrigation requirements. Furthermore, mulched compost can reduce evaporation from the soil surface, fertiliser leaching and weed growth (Pinamonti, 1998; Biala, 2000; Campell and Sharma, 2003). However, it is unclear if compost can increase soil water content and has beneficial effects on gas exchange and yield.

The aim of this study was to assess the effect of compost application on soil water content, gas exchange and yield of field grown grapevines. Our hypothesis was that compost application would increase soil water content, and therefore affect gas exchange, and improve yield and water use efficiency. Compost was applied as mulch or incorporated to determine if these two common methods of compost application differ in their effect. Compared to incorporated compost, mulched compost may reduce evaporation more strongly but may provide less nutrients.

\section{Materials and Methods}

\subsection{Experimental site}

The experiment was carried out in a 6-year old Merlot vineyard located at the Waite campus of The

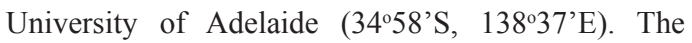
climate is Mediterranean with wet winters and hot dry summers. The soil is a clay loam at 0 to $40 \mathrm{~cm}$ (Table 1) which overlays a heavy clay at 50 to 90 $\mathrm{cm}$ depth. The shoot was vertically positioned from flowering onwards and was trimmed only if required to accommodate bird nets at veraison. Sulfur and copper were used to protect against powdery and downy mildew, respectively. The vineyard was planted with $1.8 \mathrm{~m}$ between plants and $3 \mathrm{~m}$ between rows, with rows orientated in a North to South direction. The vines were drip-irrigated three times per week for 4 hours from October - April (growing season) when required (i.e. $2 \mathrm{~L} \mathrm{~h}^{-1}$ ) equivalent to 1.5 mega litres ha ${ }^{-1}$ season $^{-1}$.

\subsection{Treatments}

Compost from garden (prunings and lawn clippings) and food waste $\left(14 \%>5 \mathrm{~mm}, 86 \% \leq 5 \mathrm{~mm}, \mathrm{pH}_{\text {water }}\right.$ 8.0, $\mathrm{EC}_{1: 5} 1.6 \mathrm{mS} \mathrm{cm}{ }^{-1}$, total $\mathrm{N} 12.7 \mathrm{~g} \mathrm{~kg}^{-1}, \mathrm{P} 2.04 \mathrm{~g}$ $\mathrm{kg}^{-1}$, and organic C $114 \mathrm{~g} \mathrm{~kg}^{-1}$, available $\mathrm{N} 25.3 \mathrm{mg}$ $\mathrm{kg}^{-1}$ and $\mathrm{P} 236.5 \mathrm{mg} \mathrm{kg}^{-1}$ ) was collected from a local commercial producer. Treatments were unamended (control) and amended at $100 \mathrm{~m}^{3} \mathrm{ha}^{-1}$ compost either incorporated (incorporation) or mulched (mulch) with 4 replicates per treatment. Compost was applied to three consecutive vines, but the data was only collected from the middle vine; two others were buffers. Compost was incorporated or mulched as a 60 $\mathrm{cm}$ wide bench of $5 \mathrm{~cm}$ thickness beneath vines in the first week of February, 2011 (i.e. three months before the first measurement of soil water content). Compost was spread on the soil surface for mulch or mixed with $0-7 \mathrm{~cm}$ of the top soil using a shovel and a garden fork for the incorporation treatment.

\subsection{Measurements}

\section{Soil water measurement}

Soil water content was measured from three months after compost application onwards with a portable soil water monitoring system (capacitance probe, Diviner 2000, Sentek Pty Ltd.,South Australia) at 10, 20, 30, 40, 50, 70 and $90 \mathrm{~cm}$ depth (Fares and Alva, 2000; Starr and Paltineanu, 2002). The access tubes were installed up to $100 \mathrm{~cm}$ soil depth (Geesing et al., 2004) Three tubes were installed for each middle vine along irrigation line (15 cm apart). One tube was installed 
One tube was installed installed directly under the dripper, near the measured middle vine, the second tube under the dripper between 2 vines and the last tube in the middle between these locations. Soil water content was measured every $6-8$ days for one year at the same time with physiological measurements at different phenological stages, and more frequently during on long dry and wet periods.

Field calibration of the Diviner was performed by correlating probe readings with volumetric water content of soil samples as described in Groves and Rose (2004). The calibration equation for the capacitance probe was derived from regression analysis of sensor measurements of scale frequency (SF) against volumetric soil water content $\left(\theta_{\mathrm{v}}\right)$ for each soil depth $(10,20,30,40,50,70$ and $90 \mathrm{~cm})$ with $\mathrm{SF}=\mathrm{a} \theta_{\mathrm{v}}^{\mathrm{b}}$. For calibration purposes, six probes were installed at the site covering a wide range of soil water contents following the procedure recommended by the manufacturer (Sentek, 2001; Polyakov et al., 2005).
Soil samples to determine soil water content and bulk density were collected using a metal core with internal diameter of $50 \mathrm{~mm}$ for each depth. At the same time, the reading of the probe was logged 10 times to obtain the average scaled frequency. The relationship between capacitance probe reading and soil water content was $\operatorname{good}\left(\mathrm{r}^{2}=0.95,0.93,0.96\right.$ and 0.83 for 10,2030 and $40 \mathrm{~cm}$ depth, respectively) only up to $40 \mathrm{~cm}$ depth whereas this relationship was poor at greater depth (in the clay horizon). Therefore only the water content up to $40 \mathrm{~cm}$ depth is presented.

A pressure plate apparatus was used to determine soil water content at matric suctions of - $10 \mathrm{kPa}$ and - $1500 \mathrm{kPa}$, which represent water potential at field capacity (FC) and permanent wilting point (PWP), respectively (Cresswell, 2002; Or and Wraith, 2002). Total available water (TAW) at each soil $10 \mathrm{~cm}$ depth increment is as the difference between the soil water content at field capacity and permanent wilting point (Cassel and Dielsen, 1986).

Table 1. Basic physical and chemical properties of vineyard soil (clay loam) at $0-10,10-20,20-30$ and $30-40$ cm depth $(n=3)$.

\begin{tabular}{|c|c|c|c|c|c|c|c|c|}
\hline \multirow{2}{*}{ Depth $(\mathrm{cm})$} & \multirow{2}{*}{$\begin{array}{l}\text { Total organic } \\
\text { carbon }\left(\mathrm{g} \mathrm{Kg}^{-1}\right)\end{array}$} & \multicolumn{2}{|c|}{ Water content ( $\mathrm{gcm}-3)$} & \multirow{2}{*}{$\begin{array}{l}\text { TAW } \\
\left(\mathrm{g} \mathrm{cm}^{-3}\right)\end{array}$} & \multirow{2}{*}{$\begin{array}{l}\text { Bulk density } \\
\left(\mathrm{g} \mathrm{cm}^{-3}\right)\end{array}$} & \multirow{2}{*}{$\begin{array}{l}\text { Total } \\
\text { porosity } \\
(\%)\end{array}$} & \multirow{2}{*}{$\mathrm{pH}$} & \multirow{2}{*}{ 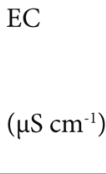 } \\
\hline & & $\mathrm{FC}$ & PWP & & & & & \\
\hline $0-10$ & 17.0 & 0.42 & 0.09 & 0.32 & 1.4 & 47.4 & 5.8 & 48.6 \\
\hline $10-20$ & 10.7 & 0.40 & 0.10 & 0.31 & 1.4 & 45.7 & $5-9$ & 40.0 \\
\hline $20-30$ & 9.0 & 0.41 & 0.11 & 0.30 & 1.5 & 42.0 & 6.0 & 43.3 \\
\hline $30-40$ & 8.9 & 0.42 & 0.14 & 0.28 & 1.6 & 39.2 & 6.1 & 51.1 \\
\hline
\end{tabular}

FC is field capacity, PWP permanent wilting point, TAW total available water, EC electrical conductivity. 


\section{Gas exchange measurements}

The photosynthetic rate $\left(\mathrm{A}, \mu \mathrm{mol} \quad \mathrm{CO}_{2} \mathrm{~m}^{-2} \mathrm{~s}^{-1}\right)$, transpiration rate $\left(\mathrm{E}, \mathrm{mmol}{ } \sqsupset_{2} \mathrm{O} \mathrm{m}^{-2} \mathrm{~s}^{-1}\right)$ and stomatal conductance $\left(\mathrm{g}_{\mathrm{s}}\right.$, mmol m $\left.\mathrm{m}^{-2} \mathrm{~s}^{-1}\right)$ were determined between 11:00 and 14:00 on two mature leaves using a gas exchange system (LCA4, ADC BioScientific Ltd, UK) at different phenological stages starting nine months after compost application. Gas exchange per plant was calculated as gas exchange per leaf area unit multiplied by total leaf area index $\left(\mathrm{m}^{2} \mathrm{~m}^{-2}\right)$ of each vine.

Midday stem water potential $\left(\Psi_{s}, \mathrm{MPa}\right)$ was measured with a pressure chamber (1005 Pressure Chamber Instrument, PMS Instrument Company, USA) (Scholander et al., 1965) at the same time as gas exchange measurements. Two mature, healthy and fully expanded leaves were selected from each plant and wrapped in plastic bags coated with aluminium foil for $20 \mathrm{~min}$. Then, the stem was cut with a razor and inserted into the chamber within 30 seconds.

\section{Plant growth measurements}

Shoot length of three marked shoots per vine was measured every second week from budburst until end of November. After that date, shoot-length measurements were not continued because of abortion and shoot tip damage. When the berries had reached pea size, chlorophyll content of three leaves of each vine was measured with a portable meter (SPAD-502 ${ }^{\circledR}$, Minolta, Japan). At harvest, all shoots were excised and the total number of chlorotic leaves counted.

Leaf area index (LAI) was measured weekly from budding until harvest (Ben-Asher et al., 2006) by using a digital camera (Cyber-shoot, Sony, Japan) following the methodology proposed by Macfarlane et al. (2007) and analysed by a script developed by Fuentes et al. (2008a) on MATLAB ${ }^{\circledR}$ (The Mathworks Inc., Natick, MA, USA). The camera was set to automatic exposure to take upward digital images.
The following vine yield components were measured: number of bunches and berry per vine, number of berries per bunch, berry weight, dry berry weight taken from random 50 berries per vine, yield, rachis weight and specific berry weight (i.e. total berry weight per total berry number per vine). Berry quality attributes such as Brix, $\mathrm{pH}$ and titratable acidity were analysed after harvest. After leaf fall, pruning weights were recorded for each vine.

\subsection{Statistical analysis}

The experiment was designed in a randomized complete design with three compost treatments (control, incorporation and mulch) with 4 replicates. Analysis of variance (ANOVA) was applied; differences between means were compared by Duncan analysis $(p \leq 0.05)$ using GenStat $^{\mathbb{R}} 11$ th $\left(\right.$ GenStat $^{\mathbb{B}}$ for Windows ${ }^{\circledR}$ 11th Edition, 2005). Data used for Principal Coordinates Analysis ( $\mathrm{PCoA}$ ) was yield, yield components (bunch number, berry number, berry number per bunch number, total berry weight, dry berry weight and specific berry weight), pruning weight, the number of chlorotic leaves and nutrient concentrations. This analysis is similar to principle component analyses (unconstrained ordination of multivariate data, projection-based), but PCoA allows much wider definition of dissimilarity and can use any chosen resemblance measure. Significant differences between treatments were determined by PERMANOVA (Primer-E Ltd, Plymouth Marine Laboratory, Plymouth, UK) based on 999 permutations

\section{Results}

3.1. Soil water content, gas exchange and stem water potential

Compared to the unamended control, mulched compost significantly increased soil water content only at $10 \mathrm{~cm}$ depth in dry and wet periods (Figure 1), and during the growing season (Figure 2), whereas incorporated 
compost had no effect. The soil water content was two-fold higher in the wet period $\left(0.3 \mathrm{~g} \mathrm{~cm}^{-3}\right)$ than in the dry period $\left(0.15 \mathrm{~g} \mathrm{~cm}^{-3}\right)$. However, compost treatment did not affect soil water content in deeper soil layers in dry and wet periods (Figure 1) or during the growing season (data not shown). Furthermore, compost did not increase the total amount of water in the soil profile (data not shown). Compared to the unamended control, compost application did not affect transpiration rate, stomatal conductance (Figure 3B and $3 \mathrm{C}$ ) or stem water potential (Table 2) at different phenological stages. The rate of photosynthesis per unit leaf area $\left(\mu \mathrm{mol} \mathrm{CO} \mathrm{CO}_{2} \mathrm{~m}^{-2} \mathrm{~s}^{-1}\right)$ was not affected by compost application, but mulched compost increased the photosynthesis per plant $\left(\mu \mathrm{mol} \mathrm{CO}{ }_{2}\right.$ vine $\left.^{-1} \mathrm{~s}^{-1}\right)$ at flowering, when the berries were pea-sized and at maturity (Figure 3A).

\subsection{Growth, yield and leaf nutrient concentrations and berry quality}

Mulched compost slightly, but not significantly increased shoot growth from day 56 (Figure 4A) and leaf area index from day 45 , compared to the control and also to incorporated compost (Figure 4A). Compost addition did not significantly increase individual yield components such as bunch number, berry number, total berry weight per vine (Table 3 ), but increased dry berry weight, specific berry weight (Table 3), and pruning weight (Table 4), particularly mulched compost. Compost addition also increased chlorophyll concentration (Table 4). Compared to the unamended control, compost increased leaf $\mathrm{N}$ and $\mathrm{P}$ concentrations, particularly the mulched compost (Table 3 ) but had no effect on leaf $\mathrm{K}$ concentration (data not shown). Total soluble solids ( $\left.{ }^{\circ} \mathrm{Brix}\right), \mathrm{pH}$ and total acidity $\left(\mathrm{g} 100 \mathrm{ml}^{-1}\right)$ were 23.2, 3.6 and 4.1, respectively, with no significant differences between the unamended control and the compost treatments.

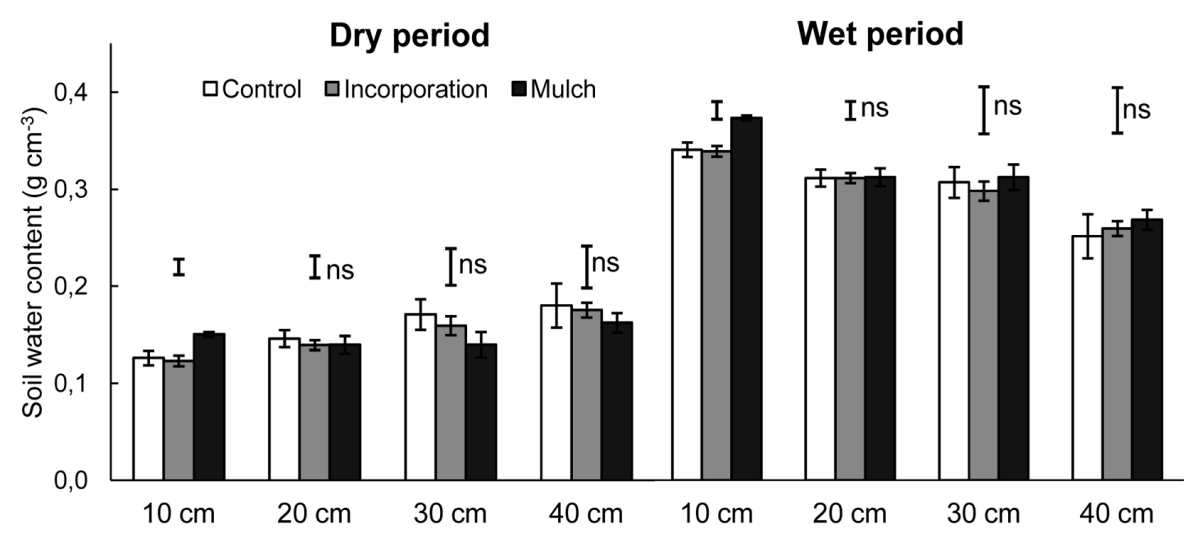

Figure 1. Soil water content $\left(\mathrm{g} \mathrm{cm}^{-3}\right)$ in dry and wet periods at different depths $(10,20,30$ and $40 \mathrm{~cm})$ in the unamended control or with incorporated or mulched compost ( $\mathrm{n}=12 \pm$ standard errror). Vertical lines are least significant difference. $n s$ is not significant. 


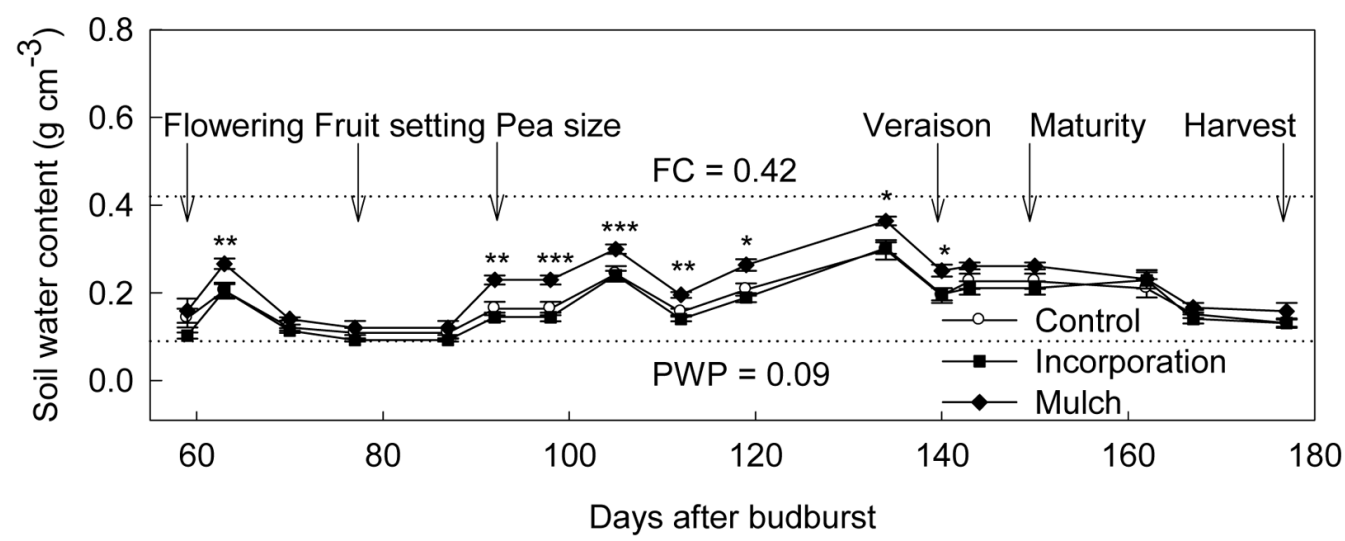

Figure 2. Soil water content throughout growing season for the unamended control (०) or with incorporated (घ) and mulched $(\star)$ compost at $10 \mathrm{~cm}$ depth $(\mathrm{n}=12 \pm$ standard error). The straight lines at the top and bottom of the graph represent the soil water content $\left(\mathrm{g} \mathrm{cm}^{-3}\right)$ at field capacity (FC) and permanent wilting point (PWP), respectively. * $p \leq 0.05, * * p \leq 0.01, * * * p \leq 0.001$.

Table 2. Midday stem water potential at different phenological stages of vine in the unamended control or with incorporated or mulched compost. Values followed by the same letter are not significantly different $(n=4)$. ns is not significant.

\begin{tabular}{lcccccc}
\hline Treatments & \multicolumn{5}{c}{ Midday stem water potential (MPa) } \\
\cline { 2 - 6 } & Flowering & Fruit setting & Pea size & Veraison & Maturity & Harvest \\
\hline Control & -0.53 & $-0.75^{\mathrm{a}}$ & $-0.58^{\mathrm{a}}$ & -1.05 & $-1.18^{\mathrm{a}}$ & $-1.02^{\mathrm{ab}}$ \\
Incorporation & -0.54 & $-0.83^{\mathrm{b}}$ & $-0.65^{\mathrm{b}}$ & -1.13 & $-1.33^{\mathrm{c}}$ & $-1.17^{\mathrm{b}}$ \\
Mulch & -0.51 & $-0.79^{\mathrm{ab}}$ & $-0.63^{\mathrm{ab}}$ & -1.09 & $-1.22^{\mathrm{b}}$ & $-1.09^{\mathrm{a}}$ \\
LSD $(P \leq 0.05)$ & $\mathrm{ns}$ & 0.07 & 0.06 & $\mathrm{~ns}$ & 0.07 & 0.06 \\
\hline
\end{tabular}




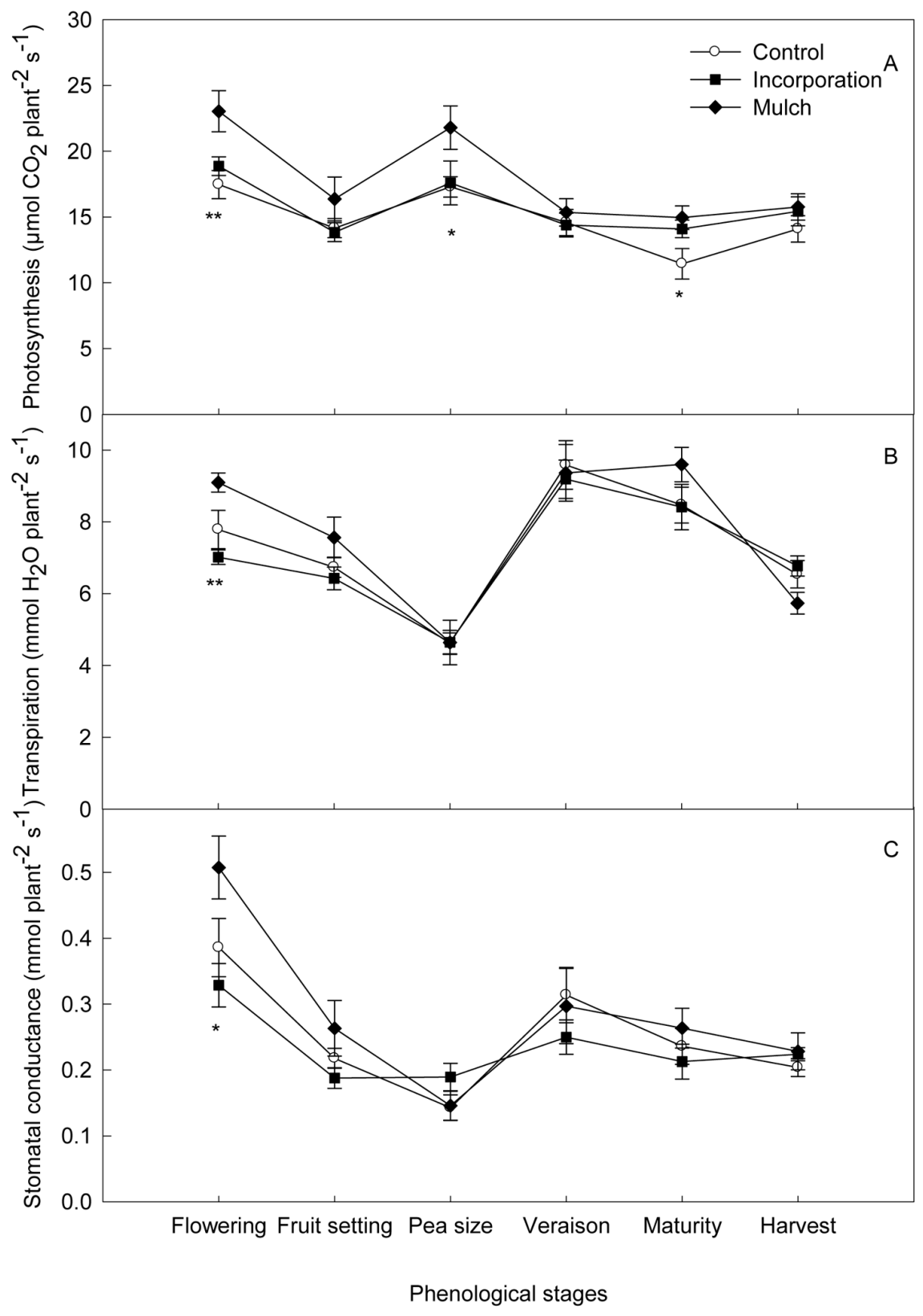

Figure 3. The rate of photosynthesis (A) and transpiration (B), and stomatal conductance (C) multiplied with leaf area index (LAI) values for unamended control $(\circ)$ or with incorporated $(\mathbf{})$ and mulched $(\diamond)$ compost at different phenological stages $\left(\mathrm{n}=4 \pm\right.$ standard error). ${ }^{*} p \leq 0.05, * * p \leq 0.01$. 


\subsection{Multivariate analysis}

The axes of the PCO plot explained 49.1\% (PCO1) and $24.1 \%$ (PCO2) of the variability in the data (Figure 5). The plot showed a clear separation between the control and the compost treatments. Compared to the unamended control, compost induced greater yield, specific berry weight, and leaf $\mathrm{N}$ concentration and reduced number of chlorotic leaves (Figure 5). The direction of the vectors indicates that yield, specific berry weight, and leaf $\mathrm{N}$ concentrations are positively correlated.

Table 3. Vine yield and yield components for $\mathrm{cv}$. Merlot in the unamended control or with incorporated or mulchedcompost. Values followed by the same letter are not significantly different $(n=4)$. ns is not significant.

\begin{tabular}{|c|c|c|c|c|c|c|c|c|}
\hline Treatment & Bunches & Berry & Berry number & Berry weight & Dry berry weight & Yield $\mathrm{F}$ & Rachis weight & ht Specific berry \\
\hline & $\left(\right.$ No. vine $\left.{ }^{-1}\right)$ & $\left(\right.$ No vine $\left.^{-1}\right)$ & per bunch & $\left(\mathrm{g}\right.$ vine $\left.\mathrm{e}^{-1}\right)$ & $\left(\mathrm{g} \text { vine } \mathrm{e}^{-1}\right)^{1}$ & $\left(\mathrm{~g}\right.$ vine $\left.\mathrm{e}^{-1}\right)$ & $\left(\mathrm{g}\right.$ vine $\left.\mathrm{e}^{-1}\right)$ & weight $\left(\mathrm{g} \mathrm{No}^{-1}\right)$ \\
\hline Control & 57 & 2827 & 49 & 3555 & $18.6^{\mathrm{a}}$ & 3740 & 184.8 & $1.2^{\mathrm{a}}$ \\
\hline Incorporation & 57 & 3260 & 57 & 4415 & $20.9^{\mathrm{ab}}$ & 4651 & 235.7 & $1.3^{\mathrm{ab}}$ \\
\hline Mulch & 48 & 3076 & 61 & 4876 & $24.1^{\mathrm{b}}$ & 5110 & 233.9 & $1.4^{\mathrm{b}}$ \\
\hline LSD $(P \leq 0.05$ & 5) $\mathrm{ns}$ & ns & ns & ns & 3.7 & ns & ns & 0.2 \\
\hline
\end{tabular}

${ }^{1}$ Data were obtained from fifty berries per ten bunches.

Table 4. Leaf nutrient concentrations, chlorophyll content, and pruning weight for $\mathrm{cv}$. Merlot in the unamended control and plots with incorporated or mulched compost. Values followed by the same letter are not significantly different $(n=4)$.

\begin{tabular}{|c|c|c|c|c|}
\hline \multirow{2}{*}{ Treatments } & \multicolumn{2}{|c|}{ Leaf nutrient concentrations $\left(\mathrm{g} \mathrm{kg}^{-1}\right)$} & \multirow{2}{*}{$\begin{array}{l}\text { Chlorophyll }^{1} \\
\text { (SPAD units) }\end{array}$} & \multirow{2}{*}{$\begin{array}{l}\text { Pruning weight } \\
\qquad\left(\text { kg vine }^{-1}\right)\end{array}$} \\
\hline & $\mathrm{N}$ & $\mathrm{P}$ & & \\
\hline Control & $15.3^{\mathrm{a}}$ & $0.9^{\mathrm{a}}$ & $34.1^{\mathrm{a}}$ & $0.55^{\mathrm{a}}$ \\
\hline Incorporation & $18.3^{\mathrm{b}}$ & $1.1^{\mathrm{ab}}$ & $36.0^{\mathrm{b}}$ & $0.72^{\mathrm{ab}}$ \\
\hline Mulch & $19.3^{\mathrm{b}}$ & $1.2^{\mathrm{b}}$ & $37.9^{\mathrm{c}}$ & $0.84^{\mathrm{b}}$ \\
\hline LSD $(P \leq 0.05)$ & 2.4 & 0.2 & 1.7 & 0.24 \\
\hline
\end{tabular}

${ }^{1}$ The chlorophyll content was measured at pea size period (84 days after budburst). 

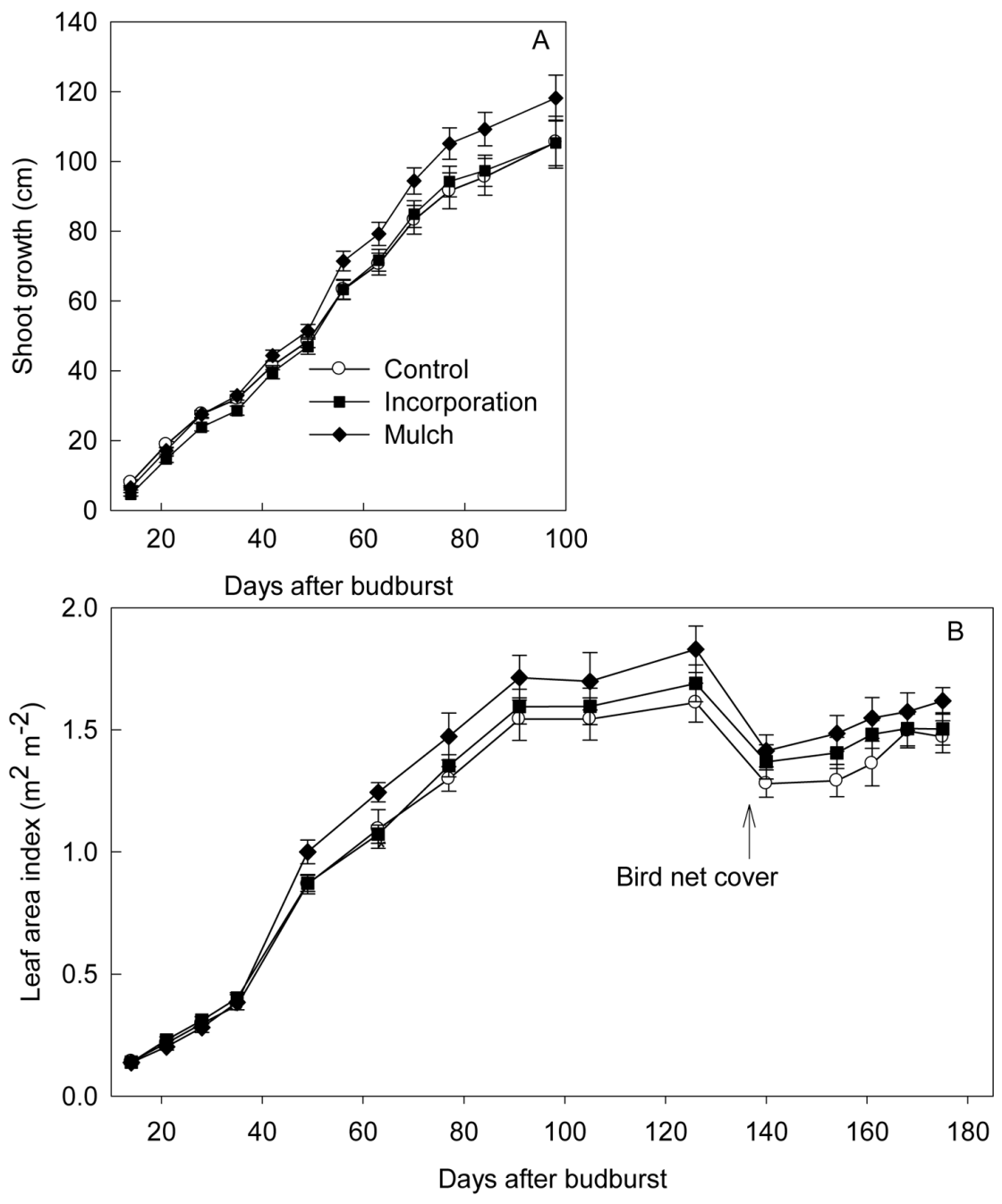

Figure 4. Shoot growth (A) and leaf area index (B) for the unamended control (O) or incorporated ( $\square$ ) and mulched ( ) compost during growing season ( $\mathrm{n}=4 \pm$ standard error). 


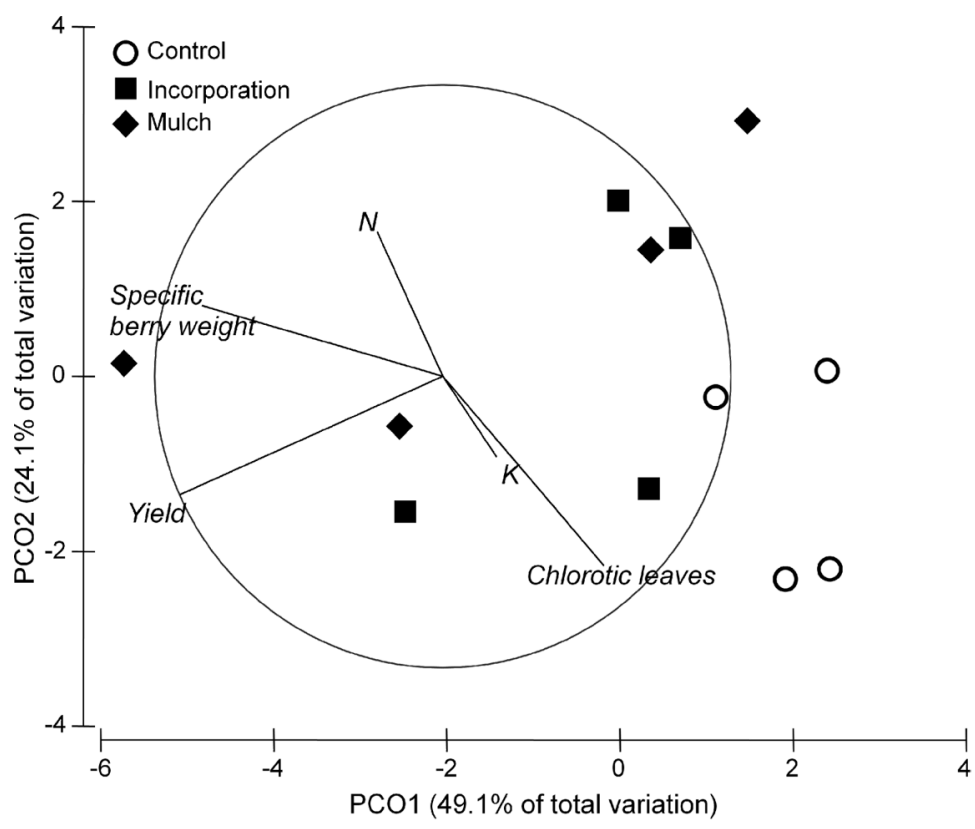

Figure 5. Principal co-ordinates analysis plot in unamended control vines (०) or with incorporated ( $\bullet$ ) or mulched ( $\downarrow)$ compost. Vectors show parameters that explain $>5 \%$ of the variance based on distance-based linear models (DistLM).

\section{Discussion}

Compost amendment was expected to increase soil water content, because mulched compost has been previously shown to reduce soil erosion by rain and runoff, and evaporation (Pinamonti, 1998). In the present study compared to the unamended control mulched compost increased soil water content only at $10 \mathrm{~cm}$ depth. This may be due to greater water holding capacity of compost and improved soil aggregation in the top soil by mulched compost (Celik et al., 2004; Sodhi et al., 2009). In addition, mulched compost can also reduce water loss by evaporation and drainage into deeper soil horizons (Pinamonti, 1998). The lack of significant effects of compost on soil water content in deeper soil layers may be due to the regular irrigation of the vineyard which avoided drying of the deeper soil layers. Most of the grapevine root biomass is below $30 \mathrm{~cm}$ depth (McKenry,
1984), therefore water uptake occurs mostly from deeper layers (Poni et al., 1994) where in the present study the water content was similar in all treatments. This can explain why neither compost treatments affected transpiration rate and stomatal conductance (Figure 3B and $3 \mathrm{C}$ ) or stem water potential (Table 2). The midday stem water potential (Table 2) indicated that grapevines were not water stressed from flowering until the berries had reached pea size (above -1.0 MPa), but they were moderately water stressed from veraison to harvest (below - 1.0 MPa) (Acevedo-Opazo et al., 2010). Mulched compost increased photosynthesis per plant $\left(\mu \mathrm{mol} \mathrm{CO} \mathrm{Clant}^{-1} \mathrm{~s}^{-1}\right)$ at flowering, when the berries were pea sized and at maturity (Figure 3A). This is due to the slightly higher leaf area index by mulched compost (Figure 4B), as mulching did not increase photosynthesis rate per $\mathrm{cm}^{-2}$ (data not shown). 
Compost application can have considerable benefits for grapevine soil management, because it can supply organic matter and plant nutrients, improve soil properties and increase yield (Pinamonti, 1998; Biala, 2000). In the present study, the increase in growth and yield observed with compost amendment can be explained by the greater leaf nutrient concentrations ( $\mathrm{N}$ and $\mathrm{P}$ ), particularly with mulched compost (Table 3 and Figure 5). This may be due to an improved soil structure and thus nutrient accessibility (Pinamonti, 1998 ) and/or nutrients added with the compost (Biala, 2000). Moreover, the greater soil water content at $10 \mathrm{~cm}$ depth (Figures 1 and 2) may also have contributed to the greater yield and specific berry weight in compost treatments. Furthermore, compost has been shown to increase root density close to the soil surface (Pinamonti, 1998), which may aid uptake of nutrients released by compost (Fuentes et al., 2008b). However, compost application did not affect grape quality attributes (data not shown). The results agree with previous findings by Pinamonti (1998) and Korboulewsky et al. (2004). Given the variable effect of compost on soil water content in the present study and the fact that the vines were irrigated it seems more likely that the positive effect of compost on vine growth and yield was due to the higher nutrient supply (Ussahatanonta et al., 1996) which is corroborated by the Principal Co-ordinates plot where leaf $\mathrm{N}$ concentrations are positively correlated with yield and specific berry weight (Figure 5).

\section{Conclusion}

This study demonstrated that garden and food waste compost did not increase soil water content in the entire soil profile in the irrigated vines. However, mulched compost increased grapevine yield with no adverse effects on grape quality. The growth increase is most likely due to the increased nutrient supply from the compost. It can be concluded that compost can be an alternative source of nutrients for sustainable vineyard management
Further research is required to investigate the long term effect of compost on grapevine physiology, growth, yield and quality under both well and waterstressed conditions.

\section{Acknowledgments}

The authors are grateful to Mr. Benjamin Pike for his help with sampling, Mr. Michael Dalton at Sentek Company for his help with probe calibration and Dr. Roberta De Bei for her technical assistance. T-T Nguyen thanks the Vietnamese Government and The University of Adelaide for the scholarship.

\section{References}

Acevedo-Opazo C., Ortega-Farias S., Fuentes S. 2010. Effects of grapevine (Vitis vinifera L.) waterstatus on water consumption, vegetative growth and grape quality: An irrigation scheduling application to achieve regulated deficit irrigation. Agric. Water Manage. 97, 956-964.

Aggelides, S.M., Londra P.A. 2000. Effects of compost produced from town wastes and sewage sludge on the physical properties of a loamy and a clay soil. Bioresour. Technol. 71, 253-259.

Ben-Asher, J., Tsuyuki, I., Bravdo, B.A., Sayih, M. 2006. Irrigation of grapevines with saline water - I. Leaf area index, stomatal conductance, transpiration and photosynthesis. Agric. Water Manage. 83, 13-21.

Biala, J. 2000. The use of recycled organics compost in viticulture: A review of the international literature and experience. In: Proceedings 6th International Congress on Organic Viticulture. Eds. H Willer, Meier, U. Stiftung Ökologie und Landbau, Convention Center Basel, Bad Dürkheim, pp. 130-134. 
Campell, A., Sharma, G. 2003. Composted Mulch For Sustainable and Productive Viticulture. Recycled Organics Unit, Sydney.

Celik, I., Ortas I., Kilic, S. 2004. Effects of compost, mycorrhiza, manure and fertilizer on some physical properties of a Chromoxerert soil. Soil and Till. Res. 78, 59-67.

Chaves, M.M., Santos, T.P., Souza, C.R., Ortuno, M.F., Rodrigues, M.L., Lopes, C.M., Maroco, J.P., Pereira, J.S. 2007. Deficit irrigation in grapevine improves water-use-efficiency without controlling vigour and production quality. Ann. Appl. Biol. $150,237-252$.

Cresswell, H.P. 2002. The soil water characteristic. In: Soil Physical Measurement and Interpretation for Land Evaluation. Eds. N MCKenzie, Coughlan, $\mathrm{K}$, Cresswell, H, CSIRO Publishing, Collingwood, Victoria. pp. 59-84.

Curtis ,M.J., Claassen, V.P. 2005. Compost incorporation increases plant available water in a drastically disturbed serpentine soil. Soil Sci. 170, 939-953.

Curtis, M.J., Claassen V.P. 2009. Regenerating topsoil functionality in four drastically disturbed soil types by compost incorporation. Restor. Ecol. 17, 24-32.

Fares, A., Alva, A.K. 2000. Evaluation of capacitance probes for optimal irrigation of citrus through soil moisture monitoring in an entisol profile. Irri. Sci. 19, 57-64.

Fuentes ,S., Palmer, A.R., Taylor, D., Zeppel, M., Whitley, R., Eamus, D. 2008a. An automated procedure for estimating the leaf area index (LAI) of woodland ecosystems using digital imagery, MATLAB programming and its application to an examination of the relationship between remotely sensed and field measurements of LAI. Funct. Plant Biol. 35, 1070-1079.
Fuentes, S., Rogers, G., Conroy, J., Jobling, J., Camus, C., Mercenaro, L. 2008b A soil-plant-atmosphere approach to evaluate the effect of irrigation strategy on Grapevine (cv. Shiraz) water and nutrient uptake, grape quality and yield. Acta Hort. 792, 297-303.

Geesing, D., Bachmaier, M., Schmidhalter, U. 2004. Field calibration of a capacitance soil water probe in heterogeneous fields. Aust. J. Soil Res. 42, 289299.

Groves, S.J., Rose, S.C. 2004. Calibration equations for Diviner 2000 capacitance measurements of volumetric soil water content of six soils. Soil Use and Manage. 20, 96-97.

Jamroz, E., Drozd, J., 1999. Influence of applying compost from municipal wastes on some physical properties of the soil. Int. Agrophy. 13, 167-170.

Korboulewsky, N., Robles, C., Garzino, S. 2004. Efects of sewage sludge compost on volatile organic compounds of wine from Vitis vinifera $\mathrm{cv}$. Red Grenache. Am. J. Enol. Viticult. 55, 412-416.

Macfarlane, C., Hoffman, M., Eamus, D., Kerp, N., Higginson, S., McMurtrie, R., Adams, M. 2007. Estimation of leaf area index in eucalypt forest using digital photography. Agr. Forest Meteorol. 143, 176-188.

McKenry, M.V. 1984. Grape root phenology relative to control of parasitic nematodes. Am. J. Enol. Viticult. 34, 206-221.

Mylavarapu, R.S., Zinati, G.M. 2009. Improvement of soil properties using compost for optimum parsley production in sandy soils. Sci. Hortic. 120, 426-430.

Or, D., Wraith, J.M. 2002. Soil water content and water potential relationships. In: Soil Physics Companion. Ed. AW Warrick, CRC Press, Boca Raton, pp. 49-82. 
Pinamonti, F. 1998. Compost mulch effects on soil fertility, nutritional status and performance of grapevine. Nutr. Cycling Agroecosyst. 51, 239-248.

Polyakov, V., Fares ,A., Ryder, M.H. 2005. Calibration of a capacitance system for measuring water content of tropical soil. Vadose Zone J. 4, 1004-1010.

Poni, S., Lakso, A.N., Turner, J.R., Melious, R.E. 1994. Interections of crop level and late season water stress on growth and physiology of field-grown Concord grapevines. Am. J. Enol. Viticult. 45, 252-258.

Powell, K.S., Burns, A., Norng, S., Granett, J., McGourty, G. 2007. Influence of composted green waste on the population dynamics and dispersal of grapevine phylloxera Daktulosphaira vitifoliae. Agri. Ecosyst. and Environ. 119, 33-38.

Sentek 2001. Calibration of the Sentek Pty Ltd Soil Moisture Sensors. Sentek, South Autralia.
Sodhi G.P.S., Beri V., Benbi D.K. 2009. Soil aggregation and distribution of carbon and nitrogen in different fractions under long-term application of compost in rice-wheat system. Soil and Till. Res. 103, 412-418.

Starr J.L., Paltineanu I.C. 2002. Capacitance devices. In: Methods of Soil Analysis Part 4 Physical Methods. Eds. JH Dane, Topp, GC. Soil Science Society of America, Inc., Madison Wisconsin, pp. 417-534.

Tejada M., Hernandez M.T., Garcia C. 2009. Soil restoration using composted plant residues: Effects on soil properties. Soil and Till. Res. 102, 109-117.

Ussahatanonta S., Jackson D.I., Rowe R.N. 1996. Effects of nutrient and water stress on vegetative and reproductive growth in Vitis vinifera L. Aust. J. Grape and Wine Res. 2, 64-69. 